\title{
Agronomic Performance of Soybean Genotypes in Lowland Paddy Fields under Zero-tillage Condition
}

\author{
Mochammad Muchlish Adie*, Ayda Krisnawati, Rudi Iswanto
}

Indonesian Legume and Tuber Crops Research Institute, Indonesia

*Email: mm_adie@yahoo.com

Submitted: 16 March 2020. Revised: 26 April 2020. Accepted: 1 June 2020

\begin{abstract}
In Indonesia, soybean is mostly cultivated in lowland following the yearly planting pattern of paddy - paddy - soybean under zero-tillage condition. The research aim was to evaluate the agronomic performance of several soybean genotypes in lowland paddy fields under zero-tillage condition. A total of 12 soybean genotypes, including the check varieties of Wilis and Anjasmoro, were evaluated in lowland after rice planting in three locations (Klaten, Pasuruan, and Tabanan). A randomized block design with four replications was used in each location. The soybean yield is a complex character which determined by interrelated agronomic characters. The averages seed yield in Klaten, Pasuruan, and Tabanan were $2.97 \mathrm{t} / \mathrm{ha}, 3.02 \mathrm{t} / \mathrm{ha}$, and $2.68 \mathrm{t} / \mathrm{ha}$, respectively. Two genotypes produced equal yield with Anjasmoro, i.e. AT12-1062 (3.01 t/ha) and AT12-1037 (3.0 t/ha). Anjasmoro variety had the highest 100 seed weight $(15.40 \mathrm{~g})$, and only AT12-1035 showed the equal seed weight. The average days to maturity of 12 genotypes was 83 days. In addition to Anjasmoro variety, soybean genotypes AT12-1062 and AT12-1037 (medium maturity and medium seed size) as the new findings form this study were potential to be developed at lowland paddy fields under zero-tillage condition. The availability of the soybean genotypes adaptive to lowland paddy field under zero tillage condition is important to optimize the soybean productivity as well as the income of farmers in Indonesia.
\end{abstract}

Key words: Adaptability; Minimum Tillage; Wetland; Yield Productivity; Zero Tillage

How to Cite: Adie, M. M., Krisnawati, A., \& Iswanto, R. (2020). Agronomic Performance of Soybean Genotypes in Lowland Paddy Fields under Zero-tillage Condition. Biosaintifika: Journal of Biology \& Biology Education, 12 (2), 140-146

DOI: http://dx.doi.org/10.15294/biosaintifika.v12i2.23263

\section{INTRODUCTION}

In Indonesia, soybeans are mostly cultivated in lowland, according to a year planting pattern of paddy - paddy - soybean. The growing season of food crops in Indonesia consists of the rainy season (November/December), first dry season (February/March), and second dry season (June/July). Soybean in the paddy fields after the rice planting is usually cultivated in the second dry season and it has become the largest soybean area in Indonesia.

Research on Anjasmoro variety which treated by tillage and zero-tillage condition did not obtain the significant yield (Tarigan, 2015). The response of soybean variety of Wilis to three ways of soil processing (only processed around the planting hole, processed once, and processed twice) also showed a non-significant yield (Raintung, 2010). Other research using Grobogan variety revealed that the combination of maximum soil treatment and the weeding time at 24 and 44 days after planting produced the highest seed yield, lowest weed dry weight, highest number of pods per plant, and the highest number of seeds per plant (Akbar, 2012). Furthermore, Hosseini et al. (2016) reported a significant increase in yield of soybean planted in a no-tillage system compared to a conventional tillage system. However, Kiszonas (2010) concluded that no differences exist between soybean grown in conventional tillage and no-tillage systems in Iowa and that locally adapted cultivars can be selected to maximize yield regardless of tillage system in Iowa. In Indonesia, soybean cultivation in the paddy field is a cultivation system that has been commonly used by farmers (Shurtleff \& Aoyagi 2010). On the contrary, zero-tillage farming or minimum tillage is widely used in USA (Mathew et al., 2012; Islam \& Reeder, 2014).

Various studies above showed that each soybean genotype responded differently to a certain environment, including zero-tillage environment. This is due to each genotype has different morphological and physiological characteristics. Even many studies found a significant interaction between genotype and environment (Yan \& Rajcan, 2002; Pereira et al., 2009; Krisnawati et al., 2016; Krisnawati \& Adie, 2018a) which indicates each genotype has a different adaptation to the specific environment. Soybean yield has been considered as a complex character, which not only determined by the adaptability to the environment but also determined by the interaction between the agronomic characters of yield components. Seed morphological characters, i.e. seed width and seed height were reported to play an important role in the yield and quality of the seed (El-Abady et al., 2012; Hu et al., 2013). Seed quality is often a prerequisite for industrial raw materials, including for indus- 
tries in Indonesia. Yield components have been reported as characters that determine the soybean yield (He et al., 2017; Ghanbari et al., 2018; Wang et al., 2010). Vu et al. (2019) found a significant positive direct effects of total number of seeds per plant and 100 seed weight on grain yield of soybean progeny. Kuswantoro et al. (2018) suggested to use the days to flowering and weight of 100 seeds as selection criteria for high yield in soybean.

The soybean farming in the lowland paddy field in Indonesia use no-tillage farming system because there is still high enough humidity, and hence, it only needs to make the irrigation channels to maintain the soil humidity. Soybean is planted no later than 10 days after the rice harvest. In order to optimize soybean productivity in the paddy field under zero-tillage condition, the identification of adaptive soybean genotype on that environment is needed. The new findings of this study are soybean genotypes with high yield potential adaptive to lowland paddy fields under zerotillage condition. The objective of the research was to evaluate the yield and agronomic performance of several soybean genotypes in the lowland paddy fields under zero-tillage condition. The results of this study were expected to produce new high-yielding soybean cultivars adaptable to lowland paddy fields in order to optimize soybean productivity and increase farmers ' income. Also, the selected lines obtained from this study can be used for gene sources in the soybean breeding program in Indonesia.

\section{METHODS}

The research material consisted of ten genotypes (AT-12-1141, AT-12-1147, AT-12-764, AT-12-273, AT-12-1041, AT-12-1062, AT-12-1037, AT-12-1058, AT-12-1035, AT-12-285) and two check varieties (Wilis and Anjasmoro). Wilis has medium seed size and medium maturity, while Anjasmoro has large seed size but medium maturity. The field experiment was conducted in three soybean production centers in Indonesia, namely Klaten (Central Java), Pasuruan (East Java), and Tabanan (Bali Island).

\section{Field Experiment}

The field experiment was conducted during the second dry season with a yearly planting pattern of paddy - paddy - soybean. On each location, the experimental design was laid out in a randomized block with four replications. The research was conducted in the lowland paddy field after rice planting under zerotillage condition. The irrigation channel was made before planting. Each genotype was planted in a $2.4 \mathrm{~m}$ $\times 4.5 \mathrm{~m}$ plot size, with $40 \mathrm{~cm} \times 10 \mathrm{~cm}$ planting distance and two seeds per hill. Plants were fertilized by
$50 \mathrm{~kg}$ Urea, $100 \mathrm{~kg} \mathrm{SP36}$, and $75 \mathrm{~kg} \mathrm{KCl}$ per ha, which applied evenly before planting. The irrigation channels were made to maintain optimum condition for soil field capacity. The weed, pests, and diseases were intensively controlled, starting from eight days after planting. Pods were harvested when $95 \%$ of the leaf turned yellow in a population.

\section{Observation and Data Analysis}

The data were categorized as main and supporting characters. The main characters consisted of seed size, days to maturity, and seed yield. The supporting characters were plant height, the number of nodes, and the number of filled and empty pods. Data were analyzed using a combined analysis of variance (ANOVA) and continued with LSD test (Least Significant Differences) at $5 \%$ level of significance.

\section{RESULTS AND DISCUSSION}

Soybean cultivation in lowland after rice planting has become the largest contributor to soybean needs in Indonesia. The characteristic for soybean cultivation after rice planting in Indonesia is without soil tillage (Figure 1). The combined ANOVA test for yield and agronomic characters showed that environment (location) was significant for all characters studied, whereas genotype was significant for all characters except for seed yield. The genotype by environment interaction (GEI) was significant for days to maturity and the number of nodes. The significant GEI revealed greater genetic variability among the soybean genotypes across environments for days to maturity and the number of nodes.

In this study, the GEI effect for seed yield was not significant, it means that genotypes have the same response to the variation of environmental conditions and the yield performance of the genotypes do not vary in three locations. The CV (coefficient of correlation) value ranged from $1.75-54.73 \%$ (Table 1). Most of the previous studies which conducted in the lowland of Indonesia showed that the CV values were under $15 \%$ (Adie et al., 2015; Krisnawati \& Adie 2018b), whereas, the study in the sub optimal land showed the CV of seed yield was generally over 15\% (Adie \& Krisnawati 2016). The lowland generally has uniform soil fertility compared to those of sub optimal land, for example acid soil and saline soil which more heterogeneous for their level of soil nutrient. 


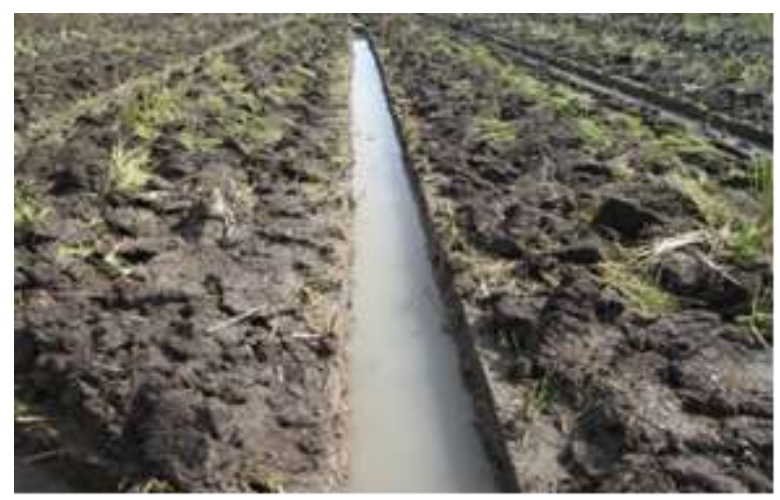

(A)

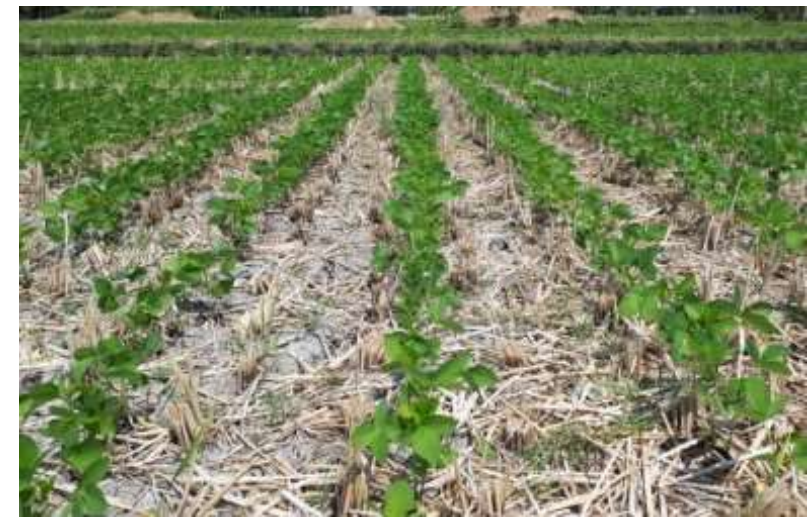

(B)

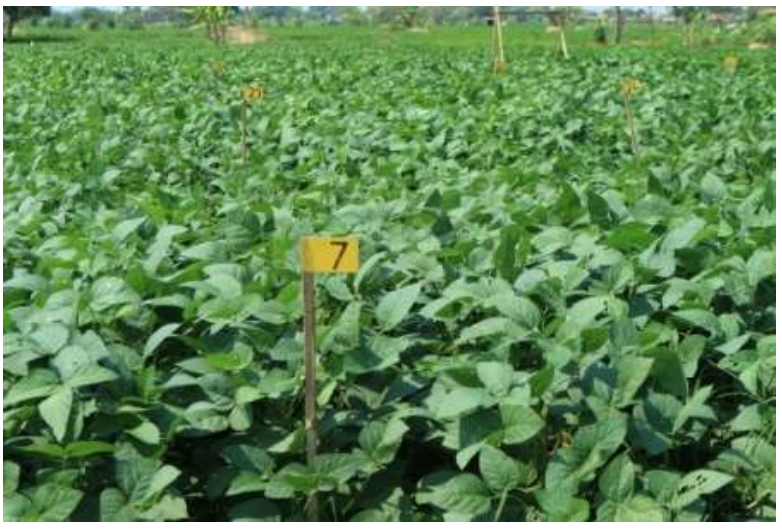

(C)

Figure 1. The field experiment of soybean in lowland: (A) no-tillage soil, (B) early growth stage, (C) generative stage

Table 1. Combined analysis of variance of yield and yield components.

\begin{tabular}{lcccc}
\hline \multirow{2}{*}{ Character } & \multicolumn{3}{c}{ Mean square } & \multirow{2}{*}{ CV $(\%)$} \\
\cline { 2 - 3 } & Location $(\mathrm{L})$ & Genotype $(\mathrm{G})$ & $\mathrm{L} \times \mathrm{G}$ & \\
\hline Days to maturity (days) & $250.8958^{* *}$ & $25.9867^{* *}$ & $13.9791^{* *}$ & 1.75 \\
Plant height $(\mathrm{cm})$ & $2778.3213^{* *}$ & $408.4195^{* *}$ & $45.1726^{\mathrm{ns}}$ & 8.47 \\
Number of node/plant & $149.0573^{* *}$ & $13.5141^{*}$ & $11.4530^{*}$ & 22.46 \\
Number of filled pod/plant & $8215.8183^{* *}$ & $195.6604^{*}$ & $103.0791^{\mathrm{ns}}$ & 18.22 \\
Number of empty pod/plant & $36.7086^{* *}$ & $0.2960^{\text {ns }}$ & $0.7513^{\text {ns }}$ & 54.73 \\
100 seed weight (g) & $60.1534^{* *}$ & $18.3513^{* *}$ & $1.0727^{\text {ns }}$ & 8.96 \\
Seed yield (t/ha) & $1.8941^{*}$ & $0.1548^{\text {ns }}$ & $0.1859^{\text {ns }}$ & 13.03 \\
\hline
\end{tabular}

Note: $\mathrm{CV}=$ coefficient of variation, $\mathrm{ns}=$ not significant, $*=$ significant at $\mathrm{p}=0.05 ; * *=$ significant at $\mathrm{p}=0.01$

The determination of the main characters was based on the preferences of soybean consumers' in Indonesia, i.e. high yield, early maturity, and large seed size. The classification of soybean maturity in Indonesia consists of early maturity ( $<80$ days), medium ( 80 - 90 days), and late maturity ( $>90$ days). The classification of soybean seed size consists of large ( $<14 \mathrm{~g} / 100$ seeds), medium $(10-14 \mathrm{~g} / 100$ seeds), and small seeded ( $<10 \mathrm{~g} / 100$ seeds).

The average yields in Klaten, Pasuruan, and Tabanan were $2.97,3.02$, and $2.68 \mathrm{t} / \mathrm{ha}$, respectively (Table 2). The location of Pasuruan produced higher yield productivity than two other locations ranged from 2.74 to $3.35 \mathrm{t} / \mathrm{ha}$. Wilis variety produced the highest yield in Pasuruan, while the yield of Anjasmoro was only $2.87 \mathrm{t} / \mathrm{ha}$. In addition to Wilis, there were six genotypes able to produce over $3.0 \mathrm{t} / \mathrm{ha}$ in Pasuruan. Range of yield in Klaten was from 2.55 - $3.16 \mathrm{t} / \mathrm{ha}$. The best genotype in Klaten was AT-121141 (3.22 t/ha) and followed by Anjasmoro (3.16 $\mathrm{t} / \mathrm{ha}$ ). In Klaten, the yield of Wilis was less optimal. In Tabanan, the yield ranged from 2.30 to $3.26 \mathrm{t} / \mathrm{ha}$ (Table 2). The best genotype in Tabanan was AT-121147 (3.26 t/ha) and followed by Anjasmoro (3.00 t/ha) (Figure 2).

The range of average yield of three locations was from $2.78-3.01 \mathrm{t} / \mathrm{ha}$, with a grand mean of $2.89 \mathrm{t} / \mathrm{ha}$ (Table 2). The average yield of Anjasmoro was 3.01 
$\mathrm{t} / \mathrm{h}$, and there were two genotypes with equal yield to Anjasmoro, i.e. AT-12-1062 (3.01 t/ha) and AT-121037 (3.00 t/ha). The average yield of Wilis was 2.84 t/ha. Based on the average yield in three locations, there was an opportunity to obtain soybean genotype adaptive to the lowland paddy field under zero-tillage condition.

The days to maturity in three locations were relatively equal, i.e. 82 days (Klaten), 84 days (Pasuruan), and 83 days (Tabanan). The range of maturity in three locations was from $80-85$ days (an average of 83 days) (Figure 3a). Based on the average of maturity, the early maturity genotype was not found. The earliest maturing genotype was AT-12-285 (80 days), and the latest maturing was Wilis ( 85 days). The averages 100 seed weight in Klaten, Pasuruan, and Tabanan were $11.21,13.08$, and $13.20 \mathrm{~g} / 100$ seed, respectively (Figure $3 \mathrm{~b}$ ). The range of seed weight from three locations was $11.34-15.40 \mathrm{~g} / 100$ seed. The 100 seed weight of Anjasmoro and Wilis were $15.40 \mathrm{~g}$ and $11.83 \mathrm{~g}$, respectively. There was a genotype with large seed size, i.e. AT-12-1035 (14.43 g/100 seed).

Table 2. Seed yield of 12 soybean genotypes in three lowland paddy fields

\begin{tabular}{lllll}
\hline \multirow{2}{*}{ Genotype } & \multicolumn{4}{c}{ Seed yield (t/ha) } \\
\cline { 2 - 5 } & Klaten & Pasuruan & Tabanan & Mean \\
\hline AT-12-1141 & 3.22 & 3.05 & 2.66 & 2.98 \\
AT-12-1147 & 2.83 & 2.82 & 3.26 & 2.97 \\
AT-12-764 & 3.00 & 2.98 & 2.35 & 2.78 \\
AT-12-273 & 3.08 & 3.04 & 2.30 & 2.81 \\
AT-12-1041 & 2.94 & 2.90 & 2.51 & 2.78 \\
AT-12-1062 & 3.03 & 3.10 & 2.91 & 3.01 \\
AT-12-1037 & 2.93 & 3.25 & 2.83 & 3.00 \\
AT-12-1058 & 2.81 & 3.14 & 2.53 & 2.83 \\
AT-12-1035 & 3.09 & 3.00 & 2.56 & 2.88 \\
AT-12-285 & 3.00 & 2.74 & 2.59 & 2.78 \\
Wilis & 2.55 & 3.35 & 2.63 & 2.84 \\
Anjasmoro & 3.16 & 2.87 & 3.00 & 3.01 \\
\hline Mean & 2.97 & 3.02 & 2.68 & 2.89 \\
\hline
\end{tabular}

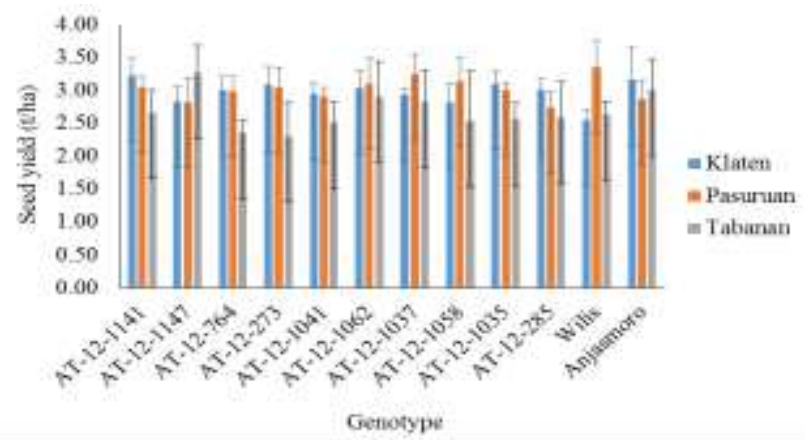

Figure 2. Seed yield of 12 soybean genotypes in three lowland paddy fields
The performance of plant height in Klaten $(58.42 \mathrm{~cm})$, Pasuruan $(70.29 \mathrm{~cm})$ and Tabanan $(72.60 \mathrm{~cm})$ varied between locations (Figure 4a). The average plant height in Klaten was shorter than two other locations. However, it was still categorized as normal height. The average plant height of three locations ranged from $54.77-73.76 \mathrm{~cm}$. Cicek et al. (2006) revealed that plant height was strongly and positively correlated with seed yield. However, in the lowland with fertile indications, plant height is not required to optimize the yield potential of soybean genotypes because they will accelerate the plant lodging, whereas in less fertile lowland, high plants will affect the increase of the number of nodes, and filled pods per plant (Kuswantoro, et al. 2018).

The average number of nodes in Klaten, Pasuruan, and Tabanan were 12.69, 9.17, and 10.80 nodes/plant, respectively (Figure 4b). Location of Klaten produced shorter plant height but the highest number of nodes per plant among all locations. The range of the number of nodes was $9.74-12.94$ nodes/plant. Wilis produced the highest number of nodes (12.94 nodes/plant), whereas Anjasmoro produced the least number of nodes (9.49 nodes/plant). The number of filled and empty pods of 12 genotypes in three locations are presented in Figure 5. The average number of filled pods in Klaten, Pasuruan, and Tabanan were $37.45,53.23$, and 63.42 filled pods/plant, respectively. The average number of empty pods in Tabanan (0.92 empty pods/plant) was less than Pasuruan (0.94 empty pods/plant). Number of the empty pods was in a few number, so that, it has less effect on the seed yield.

Machikowa and Laosuwan (2011) found that the number of pods and number of branches were important characters to obtain high yielding genotype. Furthermore, Ghodrati el al. (2013) suggested to use the number of nodes and days to maturity as a selection basis of high yielding lines. Valencia-Ramirez and Ligarreto-Moreno (2012) reported that the number of pods with three seeds per pod had a high association with seed yield.

When observing the productivity of tested genotypes (Figure 2), it was showed that there were several soybean genotypes that were not constrained by the environmental conditions of lowland areas after rice planting under zero-tillage condition. In the tropics, the agricultural system of zero-tillage has been applied which combined with the mulch application to reduce the effect of high soil temperature, high rainfall intensity, and water deficit (Jordán et al., 2011; Bhatt, 2017). 


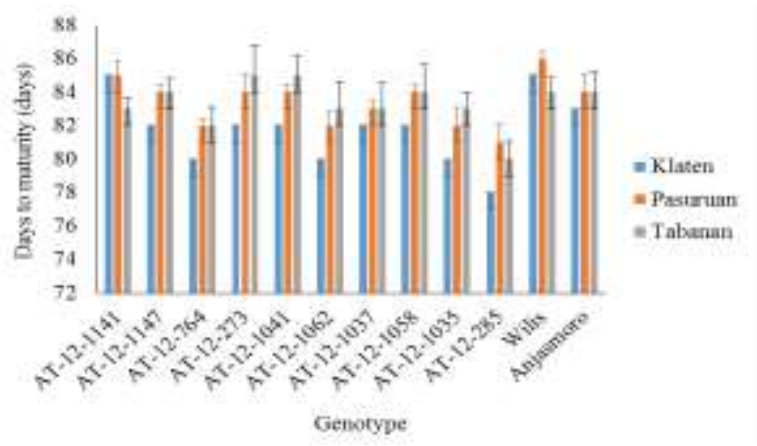

(a)

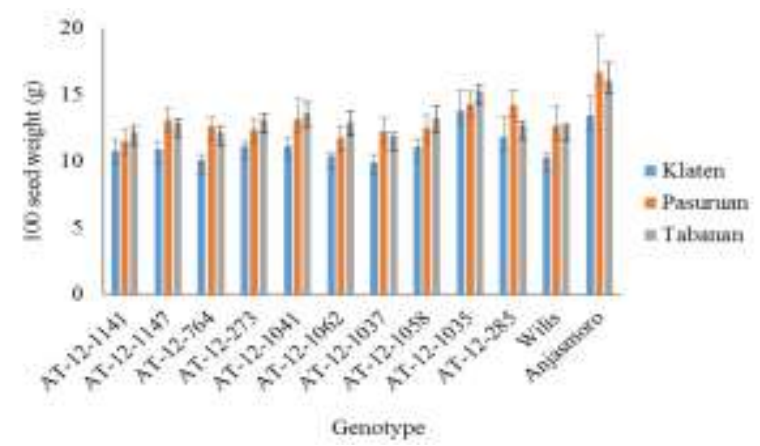

(b)

Figure 3. Days to maturity (a) and seed size (b) of 12 soybean genotypes in three lowland paddy fields

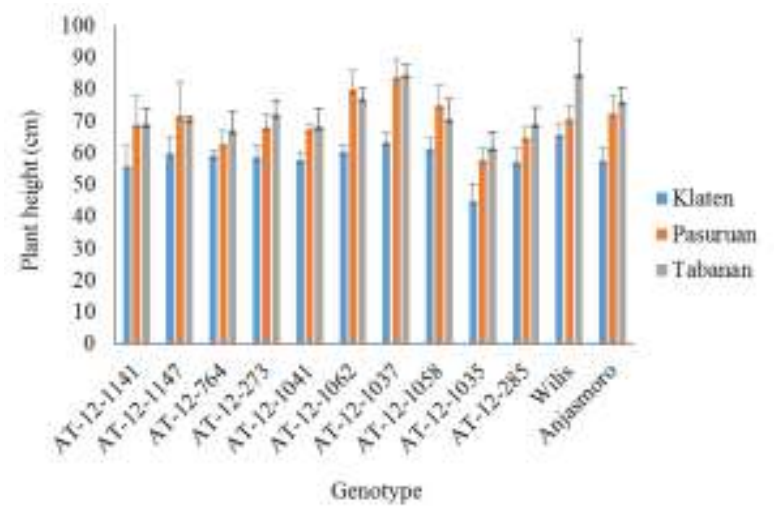

(a)

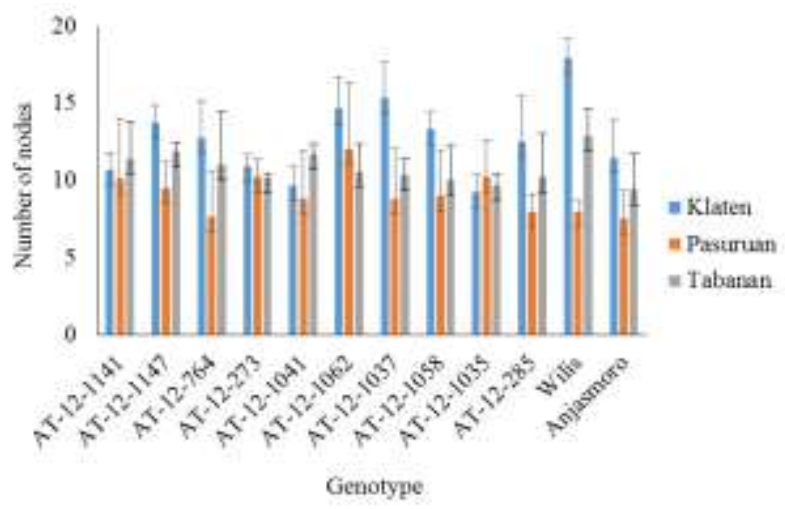

(b)

Figure 4. Plant height (a) and number of nodes (b) of 12 soybean genotypes in three lowland paddy fields



(a)

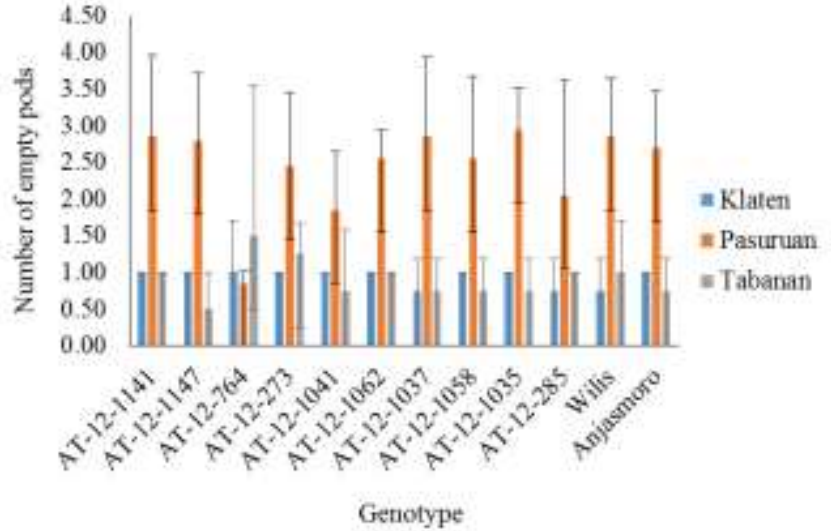

(b)

Figure 5. Number of filled and empty pod of 12 soybean genotypes in three lowland paddy fields

In the zero-tillage system, the organic matter on the surface of the soil has relatively more functions. The long-term zero-tillage system resulted in higher soil carbon and nitrogen contents, viable microbial biomass, and phosphatase activities at the $0-5 \mathrm{~cm}$ depth than the conventional tillage (Mathew et al., 2012). A zero-tillage environment caused a lower population of weed and produced a better soil quality both physically and biologically (increasing soil organic matter content, aggregate stability, and soil infiltration) that is potential to obtain optimal soybean yield.
Adaptability and yield of a soybean genotype are complex characters. In this study, the best genotypes were AT-12-1062 and AT-12-1037, with average yield in three location reached $3.0 \mathrm{t} / \mathrm{ha}$ (Table 2), which is equivalent to the yield of Anjasmoro (3.01 $\mathrm{t} / \mathrm{ha}$ ). The best two genotypes have medium seed size, meanwhile Anjasmoro has large seed size. The days to maturity of those genotypes also equivalent to Anjasmoro (medium maturity). In Indonesia, large seeded genotype is used as raw material for the tempeh industry. AT-12-1035 was classified as large seeded, but the yield was only $2.88 \mathrm{t} / \mathrm{ha}$. The earliest 
maturing genotype was AT-12-285 with a yield of $2.78 \mathrm{t} / \mathrm{ha}$.

The new findings of this study are the soybean genotypes AT-12-1062 and AT-12-1037 which adaptive to lowland paddy field with no-tillage. The result of this study recommend the development of soybean genotypes AT-12-1062, AT-12-1037 and Anjasmoro in the lowland paddy fields under zero tillage condition. The availability of these soybean genotypes is essential in order to optimize the productivity of soybean as well as the income of farmers in Indonesia.

\section{CONCLUSION}

The characteristics of soybean genotypes adaptive to the lowland paddy field under zero-tillage condition had a high number of filled pods and nodes. Soybean genotypes AT-12-1062 and AT-12-1037 which were able to produce over $3.0 \mathrm{t} / \mathrm{ha}$ is potential to be developed in a lowland paddy field under zero-tillage condition. Those genotypes have medium maturity and medium seed size.

\section{ACKNOWLEDGEMENTS}

This research was supported by the Indonesian Agency for Agricultural Research and Development (IAARD), Ministry of Agriculture RI. The authors sincerely thank Arifin for his help during the field research.

\section{REFERENCES}

Adie, M.M., \& Krisnawati, A. (2016). Identification of soybean genotypes adaptive and productive to acid soil agro-ecosystem. Biodiversitas, 17(2), 565-570.

Adie, M.M., Krisnawati, A., \& Harnowo, D. (2015). Agronomic characteristic and nutrient content from several soybean promising lines with high isoflavones. Procedia Food Science, 3, 348 - 354.

Akbar, A. (2012). The effect of soil tillage system and weeding time on the soybean growth and yield of Grobogan variety. (Sarjana Thesis, Faculty of Agriculture, University of Brawijaya). University of Brawijaya.

Bhatt, R. (2017). Zero tillage impacts on soil environment and properties. Journal of Environmental and Agricultural Sciences, 10, 1-19.

Cicek, M.S., Chen, P., Saghai M.M.A., \& Buss, G.R. (2006). Inter-relationships among agronomic and seed quality traits in an inter-specific soybean recombinant inbred population. Crop Science, 46, 1253-1259.

El-Abady, M.I., El-Emam, A.A.M., Seadh, S.E., \& Yousof, F.I. (2012). Soybean seed quality as af- fected by cultivars, threshing methods and storage periods. Research Journal of Seed Science, 5, 115125.

Ghanbari, S., Nooshkam, A., Fakheri, B.A., \& Mahdinezhad, N. (2018). Assessment of yield and yield component of soybean genotypes (Glycine $\max$ L.) in north of Khuzestan. Journal of Crop Science and Biotechnology, 21(5), 435-441.

Ghodrati, G.R., Sekhavat, R., Mahmoodinezhadedezfully, S.H., \& Gholami, A. (2013). Evaluation of correlations and path analysis of components seed yield in soybean. International Journal Agriculture: Research and Review, 3(4), 795-800.

Hosseini, S.Z., Firouzi, S., Aminpanah, H., \& Sadeghnejhad, H.R. (2016). Effect of tillage system on yield and weed populations of soybean (Glycine max L.). Anais da Academia Brasileira de Ciências, 88(1), 377-384.

He, J., Jin, Y., Du, Y.L., Wang, T., Turner, N.C., Yang, R.P., Siddique, K.H.M., \& Li, F.M. (2017). Genotypic variation in yield, yield components, root morphology and architecture, in soybean in relation to water and phosphorus supply. Frontiers in Plant Science, 8, 1499.

Hu, Z., Zhang, H., Kan, G., Ma, D., Zhang, D., Shi, G., Hong, D., Zhang, G., \& Yu, D. (2013). Determination of the genetic architecture of seed size and shape via linkage and association analysis in soybean (Glycine max L. Merr.). Genetica, 141(46), 247-254.

Islam, R., \& Reeder, R. (2014). No-till and conservation agriculture in the United States: An example from the David Brandt farm, Carroll, Ohio. International Soil and Water Conservation Research, 2(1), 97-107.

Jordán, A., Zavala, L.M., \& Muñoz-Rojas, M. (2011). Mulching, effects on soil physical properties. In Gliński, J., Horabik, J., \& Lipiec, J. (Eds.), Encyclopedia of Agrophysics. Dordrecht: Springer.

Kiszonas, A.M. (2010). Tillage effects on soybean growth, development, and yield. (Master's thesis). Retrieved from Iowa State University database.

Krisnawati, A., \& Adie, M.M. (2018a). Genotype by environment interaction and yield stability of soybean genotypes. IJAS, 19(1), 25-32.

Krisnawati, A., \& Adie, M.M. (2018b). Yield stability of soybean promising lines across environments. IOP Conference Series: Earth Environmental Science, 102, 012044.

Krisnawati, A., Basunanda, P., Nasrullah, \& Adie, M.M. (2016). Genotype stability analysis of soybean using Additive Main Effect and Multiplicative Interaction (AMMI) methods. Informatika Pertanian, 25(1), 41-50. 
Kuswantoro, H., Artari, R., Rahajeng, W., Ginting, E. \& Supeno, A. (2018). Genetic variability, heritability, and correlation of some agronomical characters of soybean varieties. Biosaintifika: Journal of Biology \& Biology Education, 10(1), 9-15.

Machikowa, T., \& Laosuwan, P. (2011). Path coefficient analysis for yield of early maturing soybean. Songklanakarin Journal of Science and Technology, 33(4), 365-368.

Mathew, R.P., Feng, Y., Githinji, L., Ankumah, R., \& Balkcom, K.S. (2012). Impact of no-tillage and conventional tillage systems on soil microbial communities. Applied and Environmental Soil Science, doi:10.1155/2012/548620.

Pereira, D.R., Bruzi, A.T., Nunes, J.A.R., Carvalho, J.P.S., Zambiazzi, E.V., \& Gesteira, G.S. (2019). Genotype $\times$ environment interactions and implications for associations among soybean traits. Genetics and Molecular Research, 18(3), 1-12.

Raintung, J.S.M. (2010). The soil tillage and yield of soybean (Glycine $\max$ L. Merill). Soil and Environment, 8(2), 65-68.

Shurtleff, W., \& Aoyagi, A. (2010). History of Soybeans and Soy foods in Southeast Asia $\left(13^{\text {th }}\right.$ Century to 2010): Extensively annotated bibliography and sourcebook. Lafayette, CA: Soyinfo Center. 1031p.

Tarigan, N.A. (2015). Efforts to increase the yield of soybean (Glycine $\max$ L.) without soil tillage system in paddy fields in Sumberejo Village, North Sumatra (Master's thesis). Retrieved from Politeknik Pertanian Negeri Payakumbuh. Tanjung Pati database.

Valencia-Ramírez, R.A., \& Ligarreto-Moreno, G.A. (2012). Phenotypic correlation and path analysis for yield in soybean (Glycine max (L.) Merril). Acta Agronómica, 61(4), 322 - 333.

Vu, T.T.H., Le, T.T.C., Vu, D.H., Nguyen, T.T., \& Ngoc, T. (2019). Correlations and path coefficients for yield related traits in soybean progenies. Asian Journal of Crop Science, 11, 32-39.

Wang, X., Wu, X., Ding, G., Yang F., Yong, T., Wang, X., \& Yang, W. (2020). Analysis of grain yield differences among soybean cultivars under maize-soybean intercropping. Agronomy, 10(1), 110.

Yan W., \& Rajcan, I. (2002). Biplot analysis of test sites and trait relations of soybean in Ontario. Crop Science, 42(1), 11-20. 